\title{
Tissue Hysteresivity Measurement
}

National Cancer Institute

\section{Source}

National Cancer Institute. Tissue Hysteresivity Measurement. NCI Thesaurus. Code C139261.

The energy dissipated relative to the elastic energy stored in the tissue in a P-V cycle. Fredberg, J.J., Stamenovic, D. (1 December 1989). On the Imperfect Elasticity of Lung Tissue. Journal of Applied Physiology, Vol. 67. Retrieved from https://owl.eng lish.purdue.edu/owl/resource/560/10/ 